\title{
Gender, Traditional Authority, and the Politics of Rural Reform in South Africa
}

\author{
Haripriya Rangan and Mary Gilmartin
}

\begin{abstract}
The new South African Constitution, together with later policies and legislation, affirm a commitment to gender rights that is incompatible with the formal recognition afforded to unelected traditional authorities. This contradiction is particularly evident in the case of land reform in many rural areas, where women's right of access to land is denied through the practice of customary law. This article illustrates the ways in which these constitutional contradictions play out with particular intensity in the 'former homelands' through the example of a conflict over land use in Buffelspruit, Mpumalanga province. There, a number of women who had been granted informal access to communal land for the purposes of subsistence cultivation had their rights revoked by the traditional authority. Despite desperate protests, they continue to be marginalized in terms of access to land, while their male counterparts appropriate communal land for commercial farming and cattle grazing. Drawing on this protest, we argue that current South African practice in relation to the pressing issue of gender equity in land reform represents a politics of accommodation and evasion that tends to reinforce gender biases in rural development, and in so doing, undermines the prospects for genuinely radical transformation of the instituted geographies and institutionalized practices bequeathed by the apartheid regime.
\end{abstract}

\section{GENDER RIGHTS AND LAND REFORM IN SOUTH AFRICA}

Seventy-year-old Josephine Tsabedze had never fallen foul of the law until she stripped naked in public on a cool Sunday in November.

When you're hungry and have abandoned grandchildren to feed, she says, there's nothing indecent about marching naked down the main street in protest.

She and 27 other rural women marched down the main road of Buffelspruit, south of Malelane in Mpumalanga, in protest against a local chief who allowed cattle to eat their maize crops. They forced surprised motorists and tourists travelling towards the Jeppe's Reef border gate with Swaziland to a halt.

'We marched all along the streets naked to show the chief that we are angry and we wanted to show him our empty stomachs', she explains defiantly. 'My main worry is the children. That's why I ended up in jail. I did all this because of hunger', she says.

The women were all arrested for a week and charged with public indecency and staging a protest without authorization.

... Their actions have not met with the approval of the entire community.

Development and Change 33(4): 633-658 (2002). (C) Institute of Social Studies 2002. Published by Blackwell Publishers, 108 Cowley Road, Oxford OX4 1JF, UK and 350 Main St., Malden, MA 02148. USA 


\footnotetext{
'Women are no good. They act kind of crazy. Wherever a woman is involved there is always trouble', says Mhlupheki Maluleka, who is one of the affected crop growers, but who is happy to wait for the chief to give him land although he has nine children to feed and an unemployed wife. 'Women are stupid', he says...
}

Reported by Nomsa Shongwe for the Africa Eye News Service in Land and Rural Digest, January/February 2000: 18-20.

It is no longer considered radical for academics, policy-makers, and practitioners engaged in international development to assert that their work needs to be informed by gender analysis, and that particular attention must be paid to the needs of poor women. As Ruth Pearson observes, the past decades of feminist activism and the entry of women into international development institutions have resulted in an increasingly high profile given to gender issues within development policies, programmes, and projects. Gender has become 'a central part of the understanding, and objective of development, providing a unique lens with which to deconstruct social institutions and processes... [it] has provided the building blocks for comprehending the reality of women's lives and the gendered nature of economic, social and political processes' (Pearson, 2000: 384).

Post-apartheid development policies in South Africa have reflected this broad trend in gender awareness. From the very outset of assuming political power, the African National Congress (ANC) government outlined a strong commitment to gender and human rights in its approach to development. It enshrined the equality between men and women in the Bill of Rights of the new Constitution, committed itself to a 'gender perspective' embedded in all its policies and programmes, and signed various conventions and declarations aimed at advancing the interests of women (Hargreaves and Meer, 2000). The Reconstruction and Development Programme (RDP) initiated in 1994 stated that development in post-apartheid South Africa was to actively involve all people and agents in a process of empowerment leading towards greater equality in gaining access to livelihood resources and democratization of authority (ANC, 1994a, 1994b). Within this context, the RDP identified land and agrarian reform as the most important issue facing the country and sought to address the subject of women's rights to land through intense national debate (Meer, 1997). The Department of Land Affairs followed by underscoring its policy commitment to gender equity in land reform (DLA, 1997). Two years later, the ANC government replaced the RDP with a more neo-liberal strategy called Growth, Employment and Redistribution (GEAR). The GEAR strategy places greater emphasis on using market mechanisms to create employment opportunities, redistribute assets, reform state institutions, and reduce poverty in urban and rural areas (May, 2000: 21), but reiterates a commitment to gender equity in land reform by setting out an 'intensified approach' involving financial assistance for women to undertake productive (i.e., market-oriented) farming, training, and capacity-building on land-related matters for women in rural areas (Turner and Ibsen, 2000: 20). 
Despite these efforts with legislation and policy, there appears to have been very little positive advancement of gender rights and land reform in post-apartheid South Africa (Daniels, 2001; Mhago and Samson, 1998; Turner and Ibsen, 2000). Tenure insecurity for women-headed households in rural areas has grown worse since the enactment of interim legislation in 1994 to protect informal land rights. Land administration in rural areas has virtually collapsed, and ongoing arguments over the new Land Rights Bill has forced the government to withdraw it for further review (Claassens, 2000; Mann, 2000; Turner and Ibsen, 2000: 15-16). All of these problems have provoked widespread criticism of the government's approach to rural development. Many scholars and activists attribute the failures to the government's abandonment of the more radical, Marxist-inspired approach toward social transformation (represented by the RDP) in favour of a neoliberal agenda that aims to please the World Bank, IMF, and other international financial institutions. Some point out that GEAR's market-led approach to development undermines previous efforts made under the RDP to implement gender equity in the land reform process (cf. Bond, 2000; Cousins, 2000; Hargreaves and Meer, 2000; Mann, 2000). There are others who argue that the government has not made land and agrarian reform part of a broader, integrated rural development process, and that its GEAR strategy invests fewer resources and little effort in improving the level of coordination between different rural development agencies and the coherence of their programmes (Turner and Ibsen, 2000: vi).

While the barrage of criticism against the government's neo-liberal turn is both understandable and largely valid, what is often overlooked in arguments over the relative virtues or weaknesses of GEAR and the RDP is the significance, not just in terms of policy but in actual practice, of linking gender equity with land reform. Although both gender equity and land reform address different, but related, dimensions of social inequality, there is little historical evidence to suggest that they have been previously viewed within a common framework for policy development or action. The vast literature on land reform experiments carried out through the post-war and decolonization periods in the twentieth century offers few insights - even in the most successful cases - regarding whether or not gender equity was consciously incorporated in the process of implementing land redistribution or tenure reform (cf. Agarwal, 1994). And even though recent trends in gender awareness have led many governments around the world to provide constitutional guarantees of equality and proclaim gender equity in land reform as integral to rural development and democracy, there is a ballooning volume of literature which copiously documents their failures in translating such laudable aims into practice. ${ }^{1}$

1. See Agarwal (1994), Hargreaves and Meer (2000), and Kabeer (1999), for overviews of the status of gender equity in land rights and development. 
The problems associated with achieving gender equity in land reform should not be merely regarded (as they often are) as the inevitable outcome of governmental hypocrisy regarding gender issues, ideological shifts in policy-making (for example, from RDP to GEAR), administrative 'corruption', or the lack of co-ordination between different agencies. Instead, we would argue that the problems emerge in large part because most development theorists and policy-makers are unable to recognize the fact that the process of linking gender equity with land reform involves bringing together two distinctive kinds of geographical agendas to make a single and - as we illustrate in the following sections of this article - complex geographic project. Land reform, as the term itself implies, is a profoundly geographical exercise that attempts to reshape the spaces of land-based production and livelihoods by redefining people's relationships of access to such resources; its aim is to literally 're-form' the instituted geographies of communities that depend in large part on land-based resources. Gender equity is also a geographical initiative in that it attempts to redefine the relationships between women and men so that they have similar abilities to gain access to livelihood resources, create spaces of public and private activity, and achieve power and status in the communal realms of their everyday lives (Carney and Watts, 1991; Guyer and Peters, 1987; Hart, 1991). The aim of gender equity, then, is to 're-form' institutions, which are themselves geographic entities produced and sustained through the lived dimensions to social life and which have, over time, developed distinctive spatial characteristics and regional identities associated with their jurisdictions, operational responsibilities, and material practices (Rangan, 2000: 177-8). Hence the process of combining the aims of gender equity with land reform becomes a complex geographic project because it calls for the simultaneous restructuring of the instituted geographies of access to land-based resources, and the redefinition of institutionalized relationships and customary practices of women and men in communities dependent on land-based production and livelihoods.

Our reasons for emphasizing the geographic dimensions of gender equity and land reform is firstly because they are central to the structuring of everyday life and material practices of communities, and secondly because these dimensions are routinely ignored or misunderstood by development theorists and policy-makers. More often than not, gender equity and land reform are viewed as 'social' issues that can be resolved in 'space' by 1) defining the ways in which land allocation should occur, and 2) stipulating the ways in which existing government agencies or NGOs should ensure even-handed distribution of lands between women and men. 'Land', in this context, is basically conceptualized as abstract space, enhanced, perhaps, by a few physical attributes, and land reform becomes a politicaleconomic exercise in redrawing boundaries of ownership by either replacing or adding to the existing groups of owners of landed property; it is, in effect, seen as 'social restructuring in space' rather than a process of reshaping 'instituted geographies'. Similarly, gender equity is inevitably regarded as a 
political exercise in accommodating the 'principles' of gender equality within the existing practices of institutions, rather than as a process of gendered reform of institutionalized relationships, conventions, and customary practices. But such approaches to gender equity and land reform inevitably create more problems than they solve because they do not pay attention to the instituted geographies of rural settlements and their significance in terms of: where lands of differing soil quality are physically located and how these are valued, owned, and used by households; where the lands or plots targeted for reform or redistribution are physically located and how these have been controlled or used in the past and present; and how those households which have previously used the lands targeted for reform might be affected by changes in ownership and resource use. These geographical dimensions are crucial because they not only reveal the ways in which institutions and institutionalized practices shape class and gendered access to land-based resources, but also indicate how changes to existing modes of access might affect the livelihood abilities and social well-being of women and men in rural communities.

In this article, we argue that the current problems associated with gender equity and land reform in South Africa are the result of political strategies that attempt, on the one hand, to accommodate post-apartheid constitutional principles within the instituted geographies of rural regions while simultaneously trying, on the other, to evade reform of institutionalized practices that have been shaped by previous colonial and apartheid regimes. We use the story of the women of Buffelspruit to illustrate the ways in which this politics of accommodation and evasion gives rise to considerable confusion and conflict, particularly within areas that are now officially referred to as 'former homelands', ${ }^{2}$ and undermines the prospects for gender equity in land reform and rural development.

The following discussion is divided into four parts. The first section examines the key contradictions emerging from the post-apartheid Constitution's delineation of traditional authority, customary law, gender rights, and democratic governance, and shows how these 'constitutional contradictions' have turned former bantustans into terrains of contention regarding issues of control over land allocation, the location of competing land-uses, and the validity of customary practices. The second section discusses the methodological approach used for making sense of the stories and reactions generated in response to the women's protest, and provides a sketch of the political economy of the Nkomazi region, the context within which the events unfolded.

2. Although the terms 'homeland' and bantustan emerged at different moments in South Africa's history and therefore carry distinctive connotations, both contain a shared geographical reference to the spaces of concentrated settlement of ethnic African populations that were controlled by or governed through 'tribal'/'traditional' authorities during colonial and apartheid rule. Hence, in this article, we use the terms interchangeably while discussing the instituted geographies of such settlements. 
The third section outlines the conjunctures and processes that culminated in the dramatic confrontation between the women of Buffelspruit and the Matsamo Traditional Authority, and examines the attempts made by regional and local institutions to solve the women's 'land problem'. The final section illustrates how the politics of accommodation and evasion tends to reinforce gender biases in land reform and rural development in South Africa and, in so doing, undermines the prospects for genuinely radical transformation of the instituted geographies and institutionalized practices bequeathed by the apartheid regime.

\section{CONSTITUTIONAL CONTRADICTIONS, LAND REFORM, AND GENDER DIMENSIONS OF RURAL POVERTY}

There are three aspects to South Africa's post-apartheid Constitution that create contradictory conditions for pursuing gender equity in land reform. These are particularly conspicuous in the former 'homelands' and bantustans which continue to function as the spaces of concentrated settlement for the majority of ethnic African populations. According to current statistics, 53 per cent of South Africans are classified as poor, and nearly 95 per cent of this impoverished population is of African ethnicity. Almost 75 per cent of poor African households live in crowded rural settlements within former homelands and bantustans (Hargreaves and Meer, 2000). Most households in these areas have access to plots ranging between 0.1 and 0.2 ha for homestead cultivation which barely secures their basic subsistence needs. High levels of unemployment in the former bantustans, along with massive retrenchments in the mining sector, means that most adult men in these households have little access to alternative sources of income for supporting their families (May, 2000). Moreover, women-headed households constitute a significant proportion - ranging between 15 and 50 per cent (Cross and Friedman, 1997; Thorp, 1997) - in these rural settlements, with little access to land or waged work (Mann, 2000). Most of them eke a tenuous living through indirect access to subsistence plots of less than 0.2 ha, and through small-scale, cash-generating activities such as harvesting a variety of natural resources such as fuelwood, grasses, medicinal and edible plants from surrounding common access lands for household use and sale (Hargreaves and Meer, 2000; May, 2000: 23; Shackleton et al., 2000).

The first contradiction is that although the new Constitution has formally abolished homelands and bantustans, it continues to protect the status of 'traditional' (previously called 'tribal') authorities who were appointed to exercise control within these jurisdictions. ${ }^{3}$ The traditional authorities were

3. South Africa Constitution 1996, Section 2 Schedule 6, and Section 211, which uphold the applicability of the old legislation. While the academic and official literature generally uses 
the means through which both colonial and apartheid governments maintained 'indirect rule' over African populations that were spatially concentrated in bantustans, a system that Mamdani (1996) aptly describes as 'decentralised despotism'. In effect, the first 'constitutional contradiction' arises from the fact that traditional authorities are officially permitted to continue exercising control over spaces of concentrated African settlement (de facto homelands), ${ }^{5}$ even though the de jure spatial categories of their administrative powers have since been abolished.

The second contradiction stems from the fact that while the post-apartheid Constitution protects the status of traditional authorities, it also enshrines a democratic Bill of Rights based on governance through elected representatives. The traditional authorities that exist in South Africa today function on the principle of hereditary rule institutionalized by previous regimes, which means that elected representatives of local governments have to contend with the presence and powers of non-elected traditional authorities whose 'former' jurisdictions fall within or overlap with the newly-defined spatial boundaries of rural municipalities (Bennett, 1995: 72, n53; Ntsebeza, 2000). The parallel recognition of elected representative government and traditional authority means that both forms of governance, despite being antithetical in principle, are expected to function alongside each other at the sub-national level.

The third contradiction is that while the Constitution accords equal rights to women and men, it simultaneously endorses the exercise of traditional customary law in former bantustan areas. Customary law does not operate on the principle of gender equality and offers few formal means through which women's independent needs or claims to land can be addressed (more on this later; see also Bekker, 1989; Bennett, 1995: 83-95; Chanock, 1985).

These three constitutional contradictions, combined with the sheer scale of

the term 'traditional authority', we have found that most people in the former homelands and bantustans generally use the term 'tribal authority'. We have, therefore, followed a similar pattern here by using 'traditional authority' in the context of theoretical discussion, and 'tribal chief' and 'tribal authority' while discussing the case study. We are also grateful to one of our anonymous referees for providing references to specific sections of the South African Constitution and other relevant legislation.

4. While there were various forms of 'tribal' rule or governance that existed in southern Africa before colonization, both the rulers and their forms of governance were not kept intact as 'tradition'; rather, many rulers were replaced, and their forms of governance transformed and bureaucratized as part of 'indirect rule' and apartheid policies. See Maylam (1986), Beinart (1994), and Mamdani (1996) for discussions of the changes to 'tradition' and 'traditional authority'.

5. They are de facto homelands because of the continued application of homeland legislation such as the Black Administration Act 38 of 1927, the Black Authorities Act 68 of 1951, and Law of Evidence Amendment Act 45 of 1988, and all the related regulations and proclamations; see Bennett (1995), chapters 4 and 5 for a detailed discussion of the application and nature of customary law and traditional leaders. 
geographically-concentrated and gendered poverty in the former homelands, only serve to intensify the existing pressures and complexities surrounding rural development and land reform. The land reform programme pursued by the South African government since 1994 has three components: restitution, redistribution, and tenure reform. Restitution involves returning lands that were appropriated since 1913 from African farming communities on the basis of past discriminatory laws and practices; ${ }^{6}$ it requires groups to submit an application to the Department of Land Affairs for the land they had occupied before being dispossessed and removed to bantustans. Redistribution aims to redress existing racial imbalances in rural land ownership, and provides financial grants for previously disadvantaged black households to buy freehold land which belonged almost exclusively to white South Africans. ${ }^{7}$ It is based on the expectation that the beneficiaries who purchase white-owned farms will make a better living by engaging in market-oriented agriculture and function as agents of economic growth in rural areas (Turner and Ibsen, 2000). While both restitution and redistribution are aimed at helping black households regain access to, or acquire ownership of, freehold lands held by white South Africans, tenure reform is wholly focused on providing safety of occupancy rights by removing the insecure and arbitrarily administered 'Permission To Occupy' (PTO) system that prevails in the former bantustans (Turner and Ibsen, 2000: v).

Although each aspect of the land reform programme has faced distinctive problems with implementation, ${ }^{8}$ tenure reform in the former homelands remains the biggest and most intractable component because of the constitutional contradictions associated with fundamental democratic rights and the customary-law powers of traditional authorities (cf. Adams et al., 2000; Bennett, 1995: 28-29; Claassens, 2000). As we mentioned earlier, the former bantustans were created by previous colonial and apartheid regimes by forcibly relocating African populations into ethnic 'homelands' in order to free up valuable land for colonists of European extraction. Until the 1990s, the apartheid government maintained a two-tier system of land ownership: white farmers were given freehold titles to land, but African households were not. It was apartheid government policy that Africans should not own land, and hence most rural areas in the homelands were officially categorized

6. For example, colonial legislation such as the Natives Land Act 27 of 1913, the Native Trust and Land Act 18 of 1936; and subsequent apartheid legislation such as the Prevention of Illegal Squatting Act 52 of 1951 and the Trespass Act 6 of 1959.

7. Households with a joint monthly income of less than R1,500 (approx. US\$ 150 in January 2002) were eligible to apply for a Settlement/Land Acquisition Grant of R 16,000 (US\$ 1600). The Communal Property Associations (CPA) Act No. 28 of 1996 allows for eligible rural households to form a group so that they can pool their grants to acquire, hold, and manage land as a collective entity; see Cousins and Hornby (2000).

8. See du Toit (2000) for problems with land restitution and Levin (2000) for problems relating to land redistribution. 
as unsurveyed and unregistered communal lands. ${ }^{9}$ The apartheid state held rural lands in trust for the apparent benefit of its occupants, but decisions regarding where and how land would be allocated to households or individuals within these areas was to be determined by traditional authorities, that is, the chiefs and their council of indunas (headmen). The allocation of land was carried out through the 'permission to occupy' (PTO) system, ${ }^{10}$ in which each induna demarcates arable fields, residential plots, and communal grazing areas within his jurisdiction after consulting with and gaining the approval of the traditional Chief and his council (Bennett, 1995: 74). Households seeking residence within the settlement are given rights of usufruct in the form of a PTO which can be revoked or terminated by the traditional authorities at their will (Claassens, 2000: 129).

Traditional authorities not only derive their power from controlling access to land occupation, but also from using African customary law to maintain social order through gendered privileges, marital status, and agebased hierarchies. Although women's customary rights can vary between different ethnic groups, ${ }^{11}$ several legal scholars have underscored the disparity between formal 'rights' and the actual power that women can exercise in their independent interests. For instance, land and cattle are crucial markers of social status and wealth for rural households in the former homelands, but customary law generally denies women 'proprietary capacity' in land because they are seen as subject to the 'guardianship' of their male relatives; similarly, in their roles as wives and mothers, women may have well-defined rights to livestock, but these rights are often circumscribed by other rules that limit their ability to independently own cattle by deeming them 'house property' (Bekker, 1989: 141-9; Bennett, 1995: 83-7). Permits to occupy land are usually registered in the name of the male representative of the household; they are rarely given to women, and almost never to unmarried men or single women (Cross and Friedman, 1997: 24). A married woman's access to land is defined by her relationship with her husband, or if deceased, through his male relatives or his sons. The level of security obtained by married women through indirect access to the PTO can vary by age, family composition, and duration of stay in the settlement. For instance, older widows may have de facto occupancy rights if they have lived in the settlement for a long time, have adult sons, or if their husband's male kin do not make claims on the plots (Cross and Friedman, 1997: 24-5). In contrast, younger women whose husbands work away from the settlement for long

9. R1036 of 1968 allowed a range of occupancy permits and leaseholds (which did not equate with ownership rights) within 'urban black areas outside rural areas'; Proclamation R293 of 1962 allowed a similar range of tenure for 'towns in black rural areas'; see Kleyn and Boraine (1992: 493-8).

10. Proclamation R188 of 1969; see Kleyn and Boraine (1992: 498-501).

11. See for instance, Section 119 of the KwaZulu Code (Act 13 of 1984); see Bekker (1989: 141-7); Bennett (1995: 89-90). 
periods and who may maintain an additional spouse are less secure because occupancy rights may be reclaimed at any time without compensation by the husband, his male relatives in the settlement, or even by the traditional authority (Mann, 2000: 2-5; Mhago and Samson, 1998).

Tenure security thus represents, in both relative and absolute terms, the most gendered component of land reform as well as the greatest challenge to traditional authority and customary land law in the former homelands (McAuslan, 1998). Its policy aim of providing secure occupancy rights to land not only undermines the role played by traditional chiefs and indunas in land allocation, but also threatens to subvert the customary rules and practices that uphold existing social hierarchies and gendered privileges in their communities. The traditional authorities face additional challenges to their official powers and domain, given the recent changes to municipal boundaries and election of new local government representatives (Cousins and Hornby, 2000; Heller, 2001). It is, therefore, not surprising to find that the representative body of traditional authorities, Contralesa (the Congress of Traditional Leaders of South Africa) has vehemently opposed tenure reform ${ }^{12}$ and the creation of new rural municipalities by invoking, among other symbols, the protection afforded to them by the South African Constitution (see Holomisa, 2000: 29; Mabuza, 2001: 1). Continuing arguments over tenure reform and local governance have led to the virtual collapse of the PTO system and land administration processes in the former bantustans (Claassens, 2000: 129). It is in this context of constitutional contradictions, administrative bedlam, and altercations over 'democratic' versus 'traditional' forms of local governance that the story of the land struggles waged by the women of Buffelspruit unfolds in stark relief.

\section{BUFFELSPRUIT: SETTING THE SCENE}

We will first present a brief explanation of our fieldwork agenda and how the investigation of the women's story relates to it. Our research project mainly focuses on the role and patterns of petty commodity extraction from common-access lands in South Africa, with a particular emphasis on understanding the economic geography of trade in plants used for traditional African medicine. The extensive geographical network of the medicinal plant trade requires us to adopt a regional political ecology approach for analysing, a) the extent to which households in different regions depend on selling medicinal plants harvested from common-access lands; and b) the different ways in which they gain access to common-access lands, and participate in this trade across rural and urban areas. Given that a significant

12. The South African government was forced to withdraw the new Land Rights Bill and place it under further review; see Claassens (2000); Turner and Ibsen (2000: 15-16). 
proportion of women and men are involved in this regionalized activity in different ways, our research examines - among other matters more specific to the plant trade - the gendered dimensions of institutional access to land and other natural resources in rural regions where medicinal plants are harvested. In short, our fieldwork agenda involves exploring any issue that provides interesting material or insights regarding the geographies of gendered access to rural resources, the gender dimensions of land reform, and institutionalized practices of local governance and natural resource management.

We happened to hear about the women of Buffelspruit during our field research in the Nkomazi region in December 1999, roughly a week after they had been arrested. Our two field translators who were from the neighbouring settlements told us what the women had done and discussed the event in scandalized tones. 'They are old women', they declared, when we asked them why the women had been compelled to strip naked in public, 'it is not right for them to do such things'. 'I think it is unconstitutional', offered one; 'especially not in front of the Chief', pronounced the other. Our curiosity was predictably aroused as we gleaned various bits of gossip and talk from the weekly markets and settlements in the region, and realized that the women's protest was not merely about gaining access to land, but more importantly about competing uses of communal land and resources within the settlement. We decided to reconstruct their story from all the gossip, rumours, and insinuations because the process promised a vivid and fascinating exploration of the lived dimensions to institutionalized practices associated with natural resource use and management in rural regions of South Africa.

Reconstructing facts from gossip, hearsay, or rumour may, at first glance, seem a spurious academic enterprise given that these are generally regarded as categories of unsubstantiated, and hence, unreliable information. But as Luise White points out, such forms of oral narrative provide everyday descriptions of extraordinary occurrences (2000: 5). Whether or not they are historically accurate, properly substantiated, or factually confirmed by all affected parties is less important than what they reveal of the lived dimensions to social life that the gossipers and rumour-mongers inhabit. While gossip and scandal assert values and define community standards, and serve as means of disciplining both the gossipers and those gossiped about, White suggests that 'rumour may simply be poised between an explanation and assertion: it is not events misinterpreted and deformed, but rather events analyzed and commented upon' (ibid.: 58). She argues that stories circulated through rumour and gossip are wonderful sources of information 'because they occupy the interstices of respectability, exactly following the contours of local and regional concerns' (ibid.: 62). They also may be the only forms of information accessible in some situations, particularly in the charged environment of a dramatic conflict or confrontation, when it may be socially awkward, even tactless, for researchers to seek details or facts from those 
directly involved in the event. Thus rather than dismissing gossip and rumour as spurious or unreliable, it is far more worthwhile to see these as rich and versatile sources of information exchange that not only provide insights into the social context of extraordinary events, but also for making sense of the contradictions and conflicts that pervade the everyday concerns and lived dimensions of communities.

Our reliance on these sources was partly due to our own situation in the field: it was extremely difficult for us to set about gathering facts or conducting detailed interviews with key actors in the conflict. Neither party could be easily approached by us in the aftermath of the event; we had heard that the chiefs were not talking about the confrontation with anyone, and we could not directly approach the women involved in the protest without immediately becoming targets of suspicion. Many people had seen us in the settlements and rural markets and they knew from talking with our translators that we were collecting information about medicinal plant gathering and trading in the region; a sudden shift in focus towards sensitive issues such as conflicts over land rights and the chief's activities would have aroused some to speculate about whether our research in the area was genuine, or merely a cover for other vested interests. Published material was also thin because there was almost no coverage of or debate over the women's protest in the local or regional media. In contrast, there was plenty of discussion and sensational comment on the impropriety of the women's behaviour in the settlements and weekly markets, where we gleaned interesting bits of information and facts that were at times consistent, and at times confusing and contradictory. It was nearly two months after the event that an article about the women's protest written by Nomsa Shongwe appeared in the Land and Rural Digest, a national-level, public interest magazine devoted to rural development issues. Shongwe's piece was extremely useful because she had managed to interview some of the women involved in the protest and other interested parties (but not the chief or other members of the Matsamo Tribal Authority), but her account of the various factors and processes leading to the event contained many of the confusing and contradictory bits of information and facts which we had also encountered in the field.

We resumed our efforts to obtain more information about the women when we returned a year later to the Nkomazi region for another season of fieldwork. This time, we decided to explore the issue of the women's claims to land through various government agencies and NGOs at the local and regional levels. Our inquiries and discussions led us to interview a fieldworker for TRAC, ${ }^{13}$ a non-government organization involved in facilitating claims for land restitution, redistribution, and tenure security. Thabo

13. The Rural Action Committee, previously known as the Transvaal Rural Action Committee. 
Malobane, the fieldworker, told us that he had been involved with the case since December 1999, when the National Land Council called on TRAC to investigate the women's protest in Buffelspruit. Our reconstruction of the events and processes leading up to the women's protest is thus based on facts gleaned from an array of sources which include Shongwe's article, newspaper reports, regional gossip and hearsay, interviews with government officials, and $\mathrm{Mr}$ Malobane's account of his fact-finding mission and subsequent efforts as a TRAC fieldworker to assist the women in obtaining secure occupancy rights to plots within their settlement. ${ }^{14}$

\section{Buffelspruit and the Transformations of the Nkomazi Region}

Buffelspruit, along with its neighbouring settlements of Schoemansdal, Driekoppies, and Jeppe's Reef, falls under the jurisdiction of the Matsamo Tribal Authority, which in turn lies within the Nkomazi region. The Nkomazi region comprises much of the eastern lowveld (lowlands) of Mpumalanga province, extending across an area bounded by the Kruger National Park to the north and the countries of Swaziland and Mozambique to the south and east; the city of Nelspruit lies to the west (see map). Malelane and Komatipoort are the two largest towns in the region, the former functioning as a tourist gateway to the southern section of Kruger National Park, and the latter as the border gateway into southern Mozambique. The national highway N4 linking the Johannesburg-Pretoria metropolitan area with Maputo, the capital of Mozambique, passes through Nelspruit, Malelane, and Komatipoort. The N4 axis is currently referred to as the 'Maputo Corridor', and is part of the 'spatial development initiative' (SDI) set out by the national government. The SDI strategy targets particular regions in different provinces for infrastructure development and provides fiscal incentives with the aim of attracting foreign direct investment and promoting economic growth through ecotourism, export-oriented agriculture, manufacturing, and producer services (Mitchell, 1998).

The eastern lowveld of Mpumalanga has been an important source of fresh fruit and vegetables for South African and international markets for at least half a century. During the late 1940s and 1950s, lands that lay within the fertile catchments of the Komati and Krokodil rivers were dispossessed from African communities and given to white farmers who produced citrus and subtropical fruit crops destined for both regional and European markets. From the 1970s onwards, there was rapid expansion of sugarcane cultivation

14. We have obtained Thabo Malobane's consent to be identified as an informant, and have obtained his approval to publish this material. The identity of informants in the regional offices of the Department of Land Affairs and the provincial Department of Housing and Land Administration have, as per their wishes, been kept confidential. 


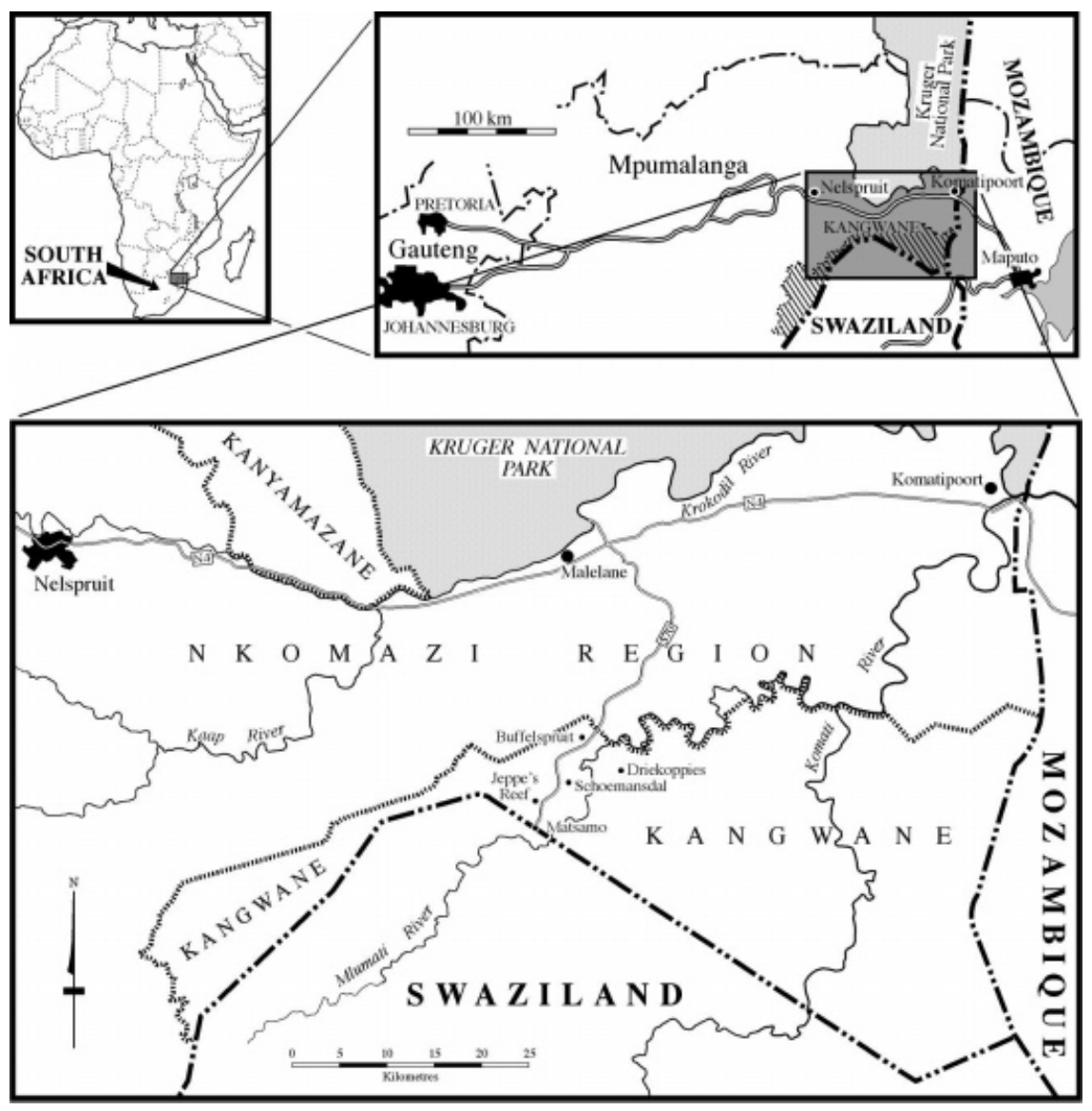

in the region; many commercial farms now grow a combination of citrus, sugarcane, and/or fruit crops such as mangoes, litchis, and bananas. Agricultural production is both capital- and labour-intensive: advanced industrial methods of irrigation, fertilization, and pest control are used in cultivation, but harvesting of sugarcane and fruit depends on labour drawn from neighbouring bantustans and migrants from Mozambique (Mather, 2000). The growth of tourism associated with Kruger National Park has also contributed to an increase in service-related activities. Several whiteowned farms and estates adjoining Kruger have been converted into private game reserves and lodges that primarily serve wealthy tourists from around the world. The highway route R570 which cuts through the Nkomazi region functions as the main conduit for tourist traffic between the kingdom of Swaziland and Kruger, linking the Jeppe's Reef/Matsamo border entry point with Malelane, which serves as the southern gateway to the national park. 
The African population in the Nkomazi region is largely concentrated in the township of KaNyamazane near Nelspruit, and in a swathe of rural settlements along the border with Swaziland, in what was the former homeland of KaNgwane (see map). Population densities in these settlements have increased since the 1970s due to forced removals as well as natural growth; many people in the region also attribute the increase in population densities to the growth in migrants from Mozambique with or without formal documentation. There are few opportunities for formal employment in the rural areas of KaNgwane. Adult men and women in most households attempt to earn money by seeking permanent or temporary work in nearby commercial farms and game lodges, or by engaging in a variety of petty commodity activities. The demand for labour in commercial farms varies according to harvest seasons, peaking between April and August during citrus harvests, and from November to February during the sugarcane, mango, and litchi seasons. Seasonal work on commercial farms is largely carried out by women and undocumented Mozambicans who are usually paid according to incentive schemes linked to piecework. Based on this system, the official monthly wages for seasonal workers can range anywhere between R240 and R700 (roughly US\$ 24 to US\$ 70 at 2002 exchange rates; see Mather, 2000: 429).

Reliable access to land has been, and continues to be, a matter of great import for households in the rural settlements of former KaNgwane. Under apartheid, the PTO system was the only means through which household members could obtain official identity documents which were necessary for seeking waged employment outside the bantustan. Now, given the limited and uncertain work opportunities in the post-apartheid/neoliberal policy era of GEAR, access to land remains the critical factor that provides households with a modicum of security and some degree of flexibility for seeking permanent or seasonal employment in surrounding areas. Social differentiation within rural settlements of KaNgwane mainly occurs on the basis of the extent to which households gain privileged access to traditional authority, land, and cattle holdings, and are able to mobilize or tap into diverse sources of income from small businesses and salaried employment. For most women-headed households, however, seasonal wage labour in commercial farms and petty extractive activities are the only sources of cash income (fieldwork 1999-2000).

Although it appears that tensions and arguments over access to land have been quotidian features of life in the rural settlements of former KaNgwane, many households in Buffelspruit and its neighbouring settlements insist that land disputes have become 'serious problems' only over the past decade since the construction of the Driekoppies dam. The dam was built following an agreement between the governments of South Africa and Swaziland to provide a secure water supply for Swaziland's needs. Households living in and around the dam site were moved to state trust lands adjoining the settlements and incorporated within the jurisdiction of the Matsamo Traditional 
Authority. Negotiations between the previous South African regime and the former KaNgwane administration resulted in the demarcation of areas for settlement of dislocated households, with approximately 1400 ha set aside as communal land for grazing cattle.

In the years that followed, the South African government launched a new policy for promoting commercial agriculture within state trust lands. The initiative enabled several of the more prosperous households in these settlement to obtain PTOs from KaNgwane's traditional authorities and begin cultivation of sugarcane, bananas, mangoes, and litchis. Around 900 ha of the area demarcated for communal grazing were brought under these plantation crops. According to local opinion, it was during this phase that disputes over land, cattle, and traditional authority intensified, and hence we have used this as the point of departure for reconstructing the historical context of the women's protests.

\section{CROPS, CATTLE, AND COMMUNAL LAND IN BUFFELSPRUIT}

The story begins between eight and ten years ago, when a group of seventeen women approached the induna of Buffelspruit and requested access to land for subsistence cultivation. All of them were poor, either widowed or without financial support from their migrant spouses, and with children to raise. Their requests were made around the time when the Matsamo Tribal Authority was granting PTOs for cultivation of sugarcane and tropical fruit on communal grazing lands. About 900 ha had already been taken up by commercial farming and pressures of settlement, thus leaving roughly 500 ha as the grazing area. It is not known whether these women offered any form of payment in cash or cattle, but the induna is said to have agreed to an informal arrangement (that is, no PTOs) and allocated them plots of less than 0.2 ha on a temporary basis within this remaining communal area. In the following years, other households in similar circumstances followed suit by requesting the induna for subsistence plots on the communal land. By 1996, there were approximately 205 households, a large proportion of them headed by women, many of whom claim to have paid R50 each (approximately US \$5) to the induna for permission to cultivate maize on subsistence plots. The total area occupied by these subsistence plots was about 25 ha, thus leaving 475 ha for communal grazing purposes.

It was around this time that Buffelspruit experienced a dramatic event which led the 205 subsistence households to organize themselves into a formal association. It is said that a young man belonging to one of these households happened to be passing by a banana plantation in the settlement when, in a moment of hunger, he plucked a fruit off the tree and ate it. The owner thereupon assaulted him, and it is said that he succumbed to his injuries. The subsistence households felt that the induna favoured the commercial farmers and was not interested in preventing such acts of violence 
against poorer members of the community. So they formed the Silwanendlala Farmers Ubuntu Association (SFUA, roughly translated as the 'fightinghunger farmers' self-upliftment' association), and elected their own induna.

The result was that Buffelspruit now bore the dubious privilege of having two indunas, one appointed and the other elected. The Chief of the Matsamo Tribal Authority refused to recognize the elected induna because he claimed that there already was an induna appointed by him for the settlement. But the Chief soon found himself at the centre of rumours which cast doubt on whether or not he was the rightful heir to the chieftaincy, that he might perhaps have occupied the position through ill-gotten means. Most people suspected that the elected induna was the source of this rumour but there was no way of tracing it back to him. Buffelspruit and other settlements under the Matsamo Tribal Authority were rife with gossip and suspicion generated around the Chief and the two indunas.

While all this was going on, the Matsamo Tribal Authority was confronted with a 'cattle-problem' within its jurisdiction. As we mentioned earlier, the expansion of commercial farming, housing, and subsistence cultivation had reduced the communal grazing area to a third of its original size, from 1400 ha to approximately 475 ha. This reduction in communal land had been accompanied by a dramatic increase in cattle numbers as commercial farmers in the settlements sought to display their enhanced wealth and status by increasing their cattle holdings. The problem came to a head when a number of traffic accidents involving stray cattle and tourist buses plying between Swaziland and Kruger Park occurred along the R570 highway. The local police went to the Matsamo Tribal Authority and requested the restriction of cattle movement in the interest of road safety. When the discussion began focusing on questions of who should be responsible for cattle numbers and their movements, the commercial farmers decided to organize themselves into the Buffelspruit Cattleowners Association.

The formation of the Buffelspruit Cattleowners Association marked another significant conjuncture in the disputes over land and traditional authority. Until then, local attention had long since been diverted from the events surrounding the formation of the SFUA and focused instead on the tensions between the elected and appointed indunas. Households in Buffelspruit and other neighbouring settlements went about their daily business, content to watch the skirmishes and stand-offs between the protagonists from the sidelines. But the 'cattle-problem' drew them all into the fray. The fastdwindling communal grazing land became the new battlefield; new lines were drawn and forces realigned. The commercial farmers - who also predictably formed the bulk of membership of the Buffelspruit Cattleowners Association - rallied around the Chief of the Matsamo Tribal Authority. As they banded together to find an 'urgent' solution, the 'cattle-problem' was transformed into a land-use altercation around 'grazing-versus-subsistence-farming'.

The Silwanendlala Farmers Ubuntu Association suddenly found itself at the centre of this newly-defined controversy. The Cattleowners Association, 
along with the Matsamo Tribal Authority, claimed that subsistence cultivation was the main cause of the 'cattle-problem', despite the fact that almost two-thirds (900 ha) of the original area set aside for communal grazing had been allotted to commercial farmers and only 25 ha occupied by the SFUA's 205 households. Members of the Cattle Association accused the households of encroaching on communal grazing lands and routinely destroying cattle fences so that they could establish more subsistence plots in the area. ${ }^{15}$ The SFUA vehemently denied these accusations and instead claimed that their members were suffering because cattle were constantly breaking through the fencing around their plots and damaging the maize crops. The Tribal Authority decided to resolve the land-use conflict by ruling that since subsistence cultivation on communal land had only been permitted on a temporary basis, it should cease after the maize harvest. But the SFUA disagreed with this decision, asserting that its members had paid the induna to secure their plots, and hence had the right to stay where they were, and ensure food security for their households.

By mid-1999, the 'grazing versus subsistence farming' problem had undergone yet another dramatic, and this time, gendered, transformation. Given that the majority of SFUA members were women-headed households, their opposition to ending subsistence farming on communal land began to be represented as a 'women-problem'. As far as the Matsamo Tribal Authority and Buffelspruit Cattle Association were concerned, the choice was clear: cattle ownership was critical to the collective well-being of their communities; the idea of reducing cattle numbers was patently absurd, it was as ridiculous as asking people to hold less money in their bank accounts. Cattle were cattle, they needed to graze and so required communal pasture; the reason they strayed was because the women had encroached on their grazing areas. In their view, the cattle problem was proving difficult to resolve because the women were recalcitrant and uninterested in working towards a cooperative solution for the collective well-being of the community.

This subtle gendered twist to the discourse enabled the Matsamo Tribal Authority and the Buffelspruit Cattleowners Association to gain political advantage in the ongoing controversy in two ways. First, it eroded male support for subsistence cultivation on communal land because men had a vested interest in cattle ownership; it was the customary way of displaying status and wealth in their communities. Second, it undermined the negotiating

15. Shongwe quotes the investigating officer, Robert Sibiya, as saying, 'When the women were first given land, they were warned it would just be for a short while, because it actually belonged to cattle farmers' (Shongwe, 2000: 19). Interestingly enough, we did not hear this argument presented to use in either the settlements or the markets. Given that former bantustans still operate under various acts that limit ownership, the officer's comment about the communal land 'belonging' to cattle farmers is not an assertion of a legal claim, but rather his matter-of-fact acceptance of the cattle owners' view that they had de facto claims over any area which may have been classified as communal grazing land. 
powers of the elected induna by putting him in the awkward position of being regarded as a mere spokesman for the interests of SFUA's female membership rather than a popularly-elected representative of the Buffelspruit community. The net result was that SFUA's women-headed households were now largely on their own when it came to defending subsistence cultivation on communal land.

Then, during the start of the spring planting season in October 1999, a series of incidents occurred which led to the dramatic protest in late November. A large proportion of SFUA's women-headed households went ahead and planted maize on their plots, thereby defying the ruling of the Matsamo Tribal Authority. They then found that the fencing around their subsistence plots was routinely damaged. The women called on the police to investigate the fence-breaking, but their inquiries yielded few results. Then, one day in late November, some of Buffelspruit's cattle-owners confronted the women while they were weeding their fields, broke the fencing, and drove in their cattle to destroy the young maize crops. The women went to the leaders of the Cattleowners Association and indignantly demanded to know how they were to feed their families. It is said that the representatives told the women it was none of their concern, that they 'could eat shit'.

The women were outraged by such a callous response to their plight. Around twenty-seven women between the ages of fifty and seventy - many of whom formed part of the original group that had requested access to plots from the local induna - decided to strip naked in front of the Chief to draw attention to their predicament. They marched naked along the main road (R570) protesting against the destruction of their maize plots, the spectacle forcing traffic on the highway to a halt. The Chief called in the police and demanded their arrest on the grounds of public indecency and for staging a protest without authorization (Shongwe, 2000: 18). Other (clothed) SFUA members who were part of the procession, including the elected induna, were not arrested.

It is said that the women remained in prison for more than a week until someone notified a public interest lawyer who came down from Nelspruit to obtain their release. By then one of the elderly women protestors who had been frail and infirm prior to the event had died in custody. On hearing about the women's protest and their travails, the National Land Council requested TRAC to alert the women of their legal rights to land. In the months that followed, the TRAC fieldworker lobbied the provincial Department of Housing and Land Administration (DHLA) on the women's behalf, urging the officials to provide a solution that addressed the needs of subsistence cultivators.

In November 2000, a year after the protest march had taken place, the DHLA organized a working committee that included officials from different provincial and local government agencies, the commercial farmers, and the Matsamo Tribal Authority, but no representative for the women protestors or the SFUA. The working committee came up with the solution of allocating 
27 ha to subsistence cultivators on the periphery of the settlement, and thereby consolidating the area designated for communal grazing (Mpumalanga News 15 February 2001). As in the case of previous allotments by the induna, the subsistence cultivators were to be given land on a temporary basis; their right to cultivate would be informally recognized but no occupancy titles or PTOs were to be provided. The working committee ruled that the DHLA, as well as the Agriculture and Conservation departments in the region were to be responsible for helping households clear the rocky terrain and bush and preparing the new plots for cultivation (AENS 5 February 2001).

The solution satisfied the Matsamo Tribal Authority and the Buffelspruit Cattleowners Association, but not the women members of the SFUA. They demanded permission to continue cultivating their original plots until the new land was cleared and prepared for planting, but the DHLA dismissed this request, declaring that the decision had been made and the problem had to be resolved as quickly as possible. Two tractors were allocated for clearing the new tracts, but one broke down within two weeks and the other ran out of fuel (AENS 5 February 2001). The TRAC fieldworker again approached the DHLA on behalf of the women, requesting the tractors be repaired and supplied with fuel but was told that the agency was constrained by limited funds. Frustrated by the lack of concern regarding the women's plight, Malobane demanded to know whether the agency proposed to continue 'resolving' all land reform issues in a similar manner, and was startled by the blunt response of one official. 'This is a political solution', he told Malobane, 'maybe not the real one; but it is the only kind of solution that is possible'.

\section{THE POLITICS OF ACCOMMODATION AND EVASION}

To claim that 'only a political solution is possible' is to state an obvious fact: all issues relating to land are fundamentally political, and so every solution involving access to land, land allocation, redistribution, or tenure security is political. The official's response to the TRAC fieldworker was, in effect, an implicit admission that the 'political solution' arrived at in the case of the women of Buffelspruit was patently unfair. Nothing had really been solved. There still was no solution to the 'cattle-straying problem'. There was almost no indication that the plots vacated by SFUA members would, in actual fact, revert to communal pasture. All that the working committee had achieved was to 'discipline' the SFUA and its women-members, first, by excluding them from the process of negotiation, and then by giving them temporary access to marginal plots on the fringe of the settlement. The political solution to the dispute over communal land-use was literally achieved by removing the 'women-problem' from its existing location to the geographical periphery and social margins of the settlement.

However, the official's defence of the 'political solution' can also be seen as a candid admission of the administrative difficulties of negotiating the 
perilous terrain created by the constitutional contradictions: that is, the introduction of democratic local governance and the protection of traditional authority, the simultaneous assertion of fundamental rights and protection of customary law. Any government official intervening on the women's behalf on the grounds of gender equity may well have been accused of sabotaging the constitutional protection accorded to traditional authority, and undermining the validity of African customary law and practices relating to land allocation and administration. Directly addressing the needs of SFUA members would not only have required challenging the power exercised by the Traditional Authority, but also the growing political and economic clout of commercial farmers in the settlements. Given these contradictions and shifting alignments of power between the national, regional and local levels, the politics of accommodation and evasion may well have been the only possible recourse available to government officials.

The successive redefinition of 'the problem' with communal land in Buffelspruit and the process of 'dispute-resolution' by the DHLA working committee offer a vivid illustration of how current approaches for dispensing gender equity in land reform are moulded by political strategies that attempt to accommodate post-apartheid constitutional principles within the instituted geographies of rural regions and, at the same time, evade reform of institutionalized practices carried on from previous colonial and apartheid regimes. Clearly, one of the main worries for households engaged in subsistence cultivation on communal land was the arbitrary power exercised by the Chief and his appointed indunas in the process of land allocation and administration. The SFUA was formed in response to the aggressive behaviour of black commercial farmers whose actions were rarely questioned or checked by the traditional authorities. The SFUA's election of an induna for Buffelspruit effectively exposed the partisan nature of the Chief and his appointees and challenged their pretensions as the 'traditional' - and therefore authentic — representatives of the collective values, needs, and aspirations of the communities. But the appearance of the 'cattleproblem' was fortuitous for the Matsamo Traditional Authority because it provided the opportunity for diverting attention away from both its own modes of functioning as well as the social tensions and disparities between commercial farmers and subsistence cultivators. The traditional authorities were then able to redefine the 'cattle-straying problem' as an issue of incompatibility of land-uses between grazing and subsistence cultivation. Despite the obvious differences in the areal distribution of land between the two forms of agriculture, it was subsistence cultivation (25 ha), not commercial farming (900 ha), that was represented as the threat to communal lands. When the majority of women-members of the SFUA opposed the ending of subsistence cultivation in their existing locations on the communal land, the Traditional Authority accused them of being troublemakers, and turned the blame on them. The 'women-problem' was not a colloquial reference to gendered problems of unequal access to land or the gender bias 
inherent in privileging commercial farming over subsistence cultivation: it was, instead, a label given to the women who drew attention to these gendered problems and were vocal with their protest. By turning the women into 'the problem', the Matsamo Traditional Authority succeeded in deflecting the focus from its biased methods of allocating land and mismanagement of communal areas, and stifling protest in the settlements.

By the time the DHLA established a working committee to resolve the dispute over communal land in Buffelspruit, there was no doubt as to which version of 'the problem' would occupy the attention of the group: it was the 'women-problem' on communal land. And even though the working committee was constituted along 'democratic' principles to include traditional authorities, appropriate government officials, and elected representatives of the newly-created municipal body, the portrayal of SFUA women-members as the 'women-problem' ensured that they would be seen as the object of discipline and control, the target of 'problem-solving', rather than as 'stakeholders' or participants in the process of 'dispute resolution'. In effect, the traditional authorities had succeeded in manipulating the politics of accommodation and evasion towards their preferred 'solution': ergo, subsistence cultivation was to cease on the communal land; alternative plots were to be allocated in a location specified and identified by them, not by the DHLA officials or the newly-elected municipal council. And, most important, it was customary law, rather than any constitutional right to gender equality that prevailed in the final decision of the working committee: plots in the new location were to be allocated to the women on a temporary basis; there was not even a whisper or vaguely-worded promise of gaining occupancy rights in the indefinite future.

The politics of accommodation and evasion around gender equity is neither unique to issues of land or tenure reform, nor restricted to administrative practices of particular provincial government agencies. As we pointed out earlier, gender equity is fundamentally a geographic initiative that seeks to redefine institutionalized relationships and customary practices of everyday life in communities, but the only way in which the post-apartheid government has dealt with the geographic dimensions of such processes is through the technocratic jargon of 'decentralization' and 'devolution' to local governments (Heller, 2001). While such terms may imply support for 'community control' or 'grassroots democracy', they do not indicate how devolution and decentralization will address issues of gender equity at the regional and local levels alongside the prevalence of traditional authority and customary law. Indeed, there is little evidence to suggest that the national government's support to various 'decentralized' administrative agencies and 'devolved' local governments is such that it enables them to intervene and ensure that gender equity is made central to the agenda of institutional reform within their jurisdictions. The language of decentralization and devolution thus becomes part of the euphemistic rhetoric routinely employed in the politics of accommodation and evasion to justify minimal engagement in gendered 
reform of institutionalized practices at the regional and local levels. The politics of accommodation and evasion is also apparent in the national government's equivocation over redefining the role of traditional authority and customary law (cf. Holomisa, 2000; James, 2000; Mabuza, 2001). And it is transparently obvious in the GEAR policies that claim to address gender equity issues in rural areas by providing women with financial assistance and training to undertake 'productive' (that is, commercial) farming and 'capacity-building on land-related matters' (Turner and Ibsen, 2000: 20).

There is no doubt that gender equity in land reform is absolutely critical to genuine democratization and rural development, and requires an enormous amount of commitment and effort to 're-form' the instituted geographies and institutional practices bequeathed by colonial and apartheid rule. 'Engendering' institutional reform is not an easy task, but nevertheless is the only way in which the government can genuinely transcend the legacies of apartheid and translate the promise of democracy and equal rights into practical realities for rural women in former bantustans. Indeed, one of the critical steps that needs to be taken by the South African government is the explicit delineation of the relative powers and distribution of responsibilities between the elected councils of rural municipalities and traditional authorities, and clear definition of the situations or contexts in which customary laws and practices should or should not hold precedence over the fundamental rights established by the Constitution.

The women of Buffelspruit were clearly aware of both the political realities and practical difficulties of securing their rights to land, livelihood, and food security in post-apartheid South Africa. They did not wait passively for the government to deliver gender equity; they did not expect, nor did they receive, any of the financial assistance and 'capacity-building in land related matters' promised by GEAR policies. Theirs was not the politics of accommodation and evasion but a political struggle for the right to occupy and cultivate their original subsistence plots and ensure food security for their households. Stripping naked was not an expression of despair or surrender, but explicitly aimed at 'baring' all the contradictions and conflicts of their everyday lives, embarrassing the Chief and his indunas, and drawing public attention to their 'empty stomachs' (Shongwe, 2000: 18). It was an act of remarkable perspicacity and courage that boldly signalled the urgent need to genuinely transform the instituted geographies and institutionalized practices of the apartheid era.

\section{Acknowledgements}

Field research in South Africa was funded by the National Science Foundation, USA, through its Geography and Regional Science Program (SBR 9709456). Our thanks to Vincent Shongwe and Calvin Khosa, our field translators, who introduced us to the story and obligingly translated 
the comments and opinions expressed by various people regarding the women's actions. We are grateful to Julia Thompson for helping us with key introductions, to Thabo Malobane at TRAC for sharing all the stories he heard in Buffelspruit, and to various government officials and households in the Nkomazi region for providing important contextual information regarding local conflicts over land allocation and land use issues. We also thank Laura Yeatman, John Friedmann, Francesca Bray, Leonie Sandercock, Sandy Robertson, Jane Jacobs, Margo Huxley, Kevin O'Connor, Paul Rogers, and the anonymous referees for their comments and suggestions

\section{REFERENCES}

Adams, M., B. Cousins and S. Manona (2000) 'Land Tenure and Economic Development in Rural South Africa: Constraints and Opportunities', in B. Cousins (ed.) At the Crossroads: Land and Agrarian Reform in South Africa into the 21st Century, pp. 111-28. Cape Town: Programme for Land and Agrarian Studies.

AENS (Africa Eye News Service) (2001) 'Women who Marched Naked now Desperate for Fuel'. 5 February.

Agarwal, B. (1994) A Field of One's Own: Gender and Land Rights in South Asia. Cambridge: Cambridge University Press.

ANC (African National Congress) (1994a) ANC Agricultural Policy. Johannesburg: Westro Press.

ANC (1994b) Basic Guide to the RDP [Reconstruction and Development Programme]. Johannesburg: Aloe Press.

Beinart, W. (1994) Twentieth-Century South Africa. Oxford: Oxford University Press.

Bekker, J. C. (1989) Seymour's Customary Law in Southern Africa (5th edn). Cape Town: Juta Press.

Bennett, T. W. (1995) Human Rights and African Customary Law. Cape Town: Juta Press.

Bond, P. (2000) Elite Transition: From Apartheid to Neoliberalism in South Africa. London: Pluto Press; Pietermaritzburg: University of Natal Press.

Carney, J. and M. Watts (1991) 'Disciplining Women? Rice, Mechanization, and the Evolution of Mandinka Gender Relations in Senegambia', Signs 16: 651-81.

Chanock, M. (1985) Law, Custom and Social Order: The Colonial Experience in Malawi and Zambia. Cambridge: Cambridge University Press.

Claassens, A. (2000) 'Land Rights and Local Decision-making Processes: Proposals for Tenure Reform', in B. Cousins (ed.) At the Crossroads: Land and Agrarian Reform in South Africa into the 21st Century, pp. 129-42. Cape Town: Programme for Land and Agrarian Studies.

Cousins, B. (2000) 'Does Land and Agrarian Reform have a Future, and if so, Who will Benefit?', in B. Cousins (ed.) At the Crossroads: Land and Agrarian Reform in South Africa into the 21st Century, pp. 1-8. Cape Town: Programme for Land and Agrarian Studies.

Cousins, T. and D. Hornby (2000) 'Leaping the Fissures: Bridging the Gap between Paper and Real Practice in Setting up Common Property Institutions in Land Reform in South Africa'. Paper prepared for presentation in the Legal Aspects of Governance of CBNRM. CASS/ PLAAS CBNRM Programme 2nd Annual Regional Meeting (16-17 October).

Cross, C. and M. Friedman (1997) 'Women and Tenure: Marginality and the Left-hand Power', in S. Meer (ed.) Women, Land, and Authority: Perspectives from South Africa, pp. 17-34. Cape Town and Oxford: David Philip and Oxfam, in association with the National Land Committee.

Daniels, G. (2001) 'Rural Women to Fight for their Right to Land', Weekly Mail \& Guardian 1-7 June. 
Department of Land Affairs (1997) White Paper on South African Land Policy. Pretoria: DLA National Office.

Guyer, J. and P. Peters (1987) 'Introduction to Special Issue: Conceptualizing the Household: Issues of Theory and Policy in Africa', Development and Change 18(2): 197-214.

Hargreaves, S. and S. Meer (2000) 'Out of the Margins and into the Centre: Gender and Institutional Change', in B. Cousins (ed.) At the Crossroads: Land and Agrarian Reform in South Africa into the 21st Century, pp. 264-79. Cape Town: Programme for Land and Agrarian Studies.

Hart, G. (1991) 'Engendering Everyday Resistance: Gender, Patronage, and Production Politics in Rural Malaysia', Journal of Peasant Studies 19(1): 93-121.

Heller, P. (2001) 'Moving the State: The Politics of Democratic Decentralization in Kerala, South Africa, and Porto Alegre', Politics and Society 29(1): 131-63.

Holomisa, P. (2000) 'Ubukhosi the Bedrock of African Democracy', Weekly Mail \& Guardian 11-17 February.

James, D. (2000) 'Hill of Thorns: Custom, Knowledge, and the Reclaiming of a Lost Land in the New South Africa', Development and Change 31(3): 629-49.

Kabeer, N. (1999) 'Resources, Agency, Achievements: Reflections on the Measurement of Women's Empowerment', Development and Change 30(3): 435-64.

Kleyn, D. G. and A. Boraine (1992) Silberberg and Schoeman's The Law of Property (3rd edn). Durban: Butterworths.

Levin, R. (2000) 'Towards a National Strategy for Land Redistribution', in B. Cousins (ed.) At the Crossroads: Land and Agrarian Reform in South Africa into the 21st Century, pp. 68-74. Cape Town: Programme for Land and Agrarian Studies.

Mabuza, J. (2001) 'Amakhosi in the Dark', Mpumalanga News 1 February.

Mamdani, M. (1996) Citizen and Subject: Contemporary Africa and the Legacy of Late Colonialism. Princeton, NJ: Princeton University Press.

Mann, M. (2000) 'Women's Access to Land in the Former Bantustans: Constitutional Conflict, Customary Law, Democratization and the Role of the State'. Occasional Paper No 15. Cape Town: Programme for Land and Agrarian Studies.

Mather, C. (2000) 'Foreign Migrants in Export Agriculture: Mozambican Labour in the Mpumalanga Lowveld, South Africa', Tijdschrift voor Economische en Sociale Geografie 91(4): 426-36.

May, J. (2000) 'The Structure and Composition of Rural Poverty and Livelihoods in South Africa', in B. Cousins (ed.) At the Crossroads: Land and Agrarian Reform in South Africa into the 21st Century, pp. 21-34. Cape Town: Programme for Land and Agrarian Studies.

Maylam, P. (1986) A History of the African People of South Africa: From the Early Iron Age to the 1970s. Cape Town and Johannesburg: David Philip.

McAuslan, P. (1998) 'Making Law Work: Restructuring Land Relations in Africa', Development and Change 29(3): 525-52.

Meer, S. (1997) 'Introduction', in S. Meer (ed.) Women, Land and Authority: Perspectives from South Africa, pp. 1-14. Cape Town and Oxford: David Philip and Oxfam, in association with the National Land Committee.

Mhago, F. and M. Samson (1998) 'A Gender Analysis of Recent South African Land Reform', in Women's Land and Property Rights in Situations of Conflict and Reconstruction. United Nations Development Fund for Women (UNIFEM) at http://www.undp.org/unifem/public/ landrights (accessed 30 November 2001).

Mitchell, J. (1998) 'The Maputo Development Corridor: A Case Study of the SDI Process in Mpumalanga', Development Southern Africa 15(5): 757-69.

Mpumalanga News (2001) 'Land Dispute Resolved', 15 February.

Ntsebeza, L. (2000) 'Traditional Authorities, Local Government, and Land Rights', in B. Cousins (ed.) At the Crossroads: Land and Agrarian Reform in South Africa into the 21st Century, pp. 280-305. Cape Town: Programme for Land and Agrarian Studies.

Pearson, R. (2000) 'Rethinking Gender Matters in Development', in T. Allen and A. Thomas (eds) Poverty and Development into the 21st Century, pp. 383-402. Oxford: Oxford University Press in association with the Open University. 
Rangan, H. (2000) Of Myths and Movements: Rewriting Chipko into Himalayan History. London: Verso.

Shackleton, S. E., C. C. Shackleton and B. Cousins (2000) 'The Economic Value of Land and Natural Resources to Rural Livelihoods: Case Studies from South Africa', in B. Cousins (ed.) At the Crossroads: Land and Agrarian Reform in South Africa into the 21st Century, pp. 35-67. Cape Town: Programme for Land and Agrarian Studies.

Shongwe, N. (2000) 'Women Strip Naked to show Hungry Stomachs', Land and Rural Digest 10 (January/February).

Thorp, L. (1997) 'Access to Land: A Rural Perspective on Tradition and Resources', in S. Meer (ed.) Women, Land, and Authority: Perspectives from South Africa, pp. 35-44. Cape Town and Oxford: David Philip and Oxfam, in association with the National Land Committee.

du Toit, A. (2000) 'The End of Restitution: Getting Real about Land Claims', in B. Cousins (ed.) At the Crossroads: Land and Agrarian Reform in South Africa into the 21st Century, pp. 75-91. Cape Town: Programme for Land and Agrarian Studies.

Turner, S. and H. Ibsen (2000) Land and Agrarian Reform in South Africa: A Status Report funded by the Government of Norway through the Norwegian Institute of Human Rights, University of Oslo. Cape Town: Programme for Land and Agrarian Studies, University of Western Cape, and Centre for International Environment and Development Studies, Agricultural University of Norway.

White, L. (2000) Speaking with Vampires: Rumour and History in Colonial East Africa. Berkeley and Los Angeles, CA: University of California Press.

Haripriya Rangan is Senior Lecturer in Human Geography at the School of Geography and Environmental Science, Monash University-Clayton, Melbourne, VIC 3800, Australia (haripriya.rangan@arts. monash.edu.au). She has been researching the geography of the medicinal plant trade in South Africa over the past three years. Her previous research has focused on issues of regional development, resource-based conflicts, and natural resource management in the Indian Himalayas.

Mary Gilmartin is Lecturer in Human Geography at Nottingham-Trent University, UK (mary.gilmartin@ntu.ac.uk). Her research focuses on the politics of education reform in South Africa and Northern Ireland. She worked as a research assistant with Priya Rangan in South Africa. 